\begin{tabular}{|c|c|c|}
\hline & PORT SAID ENGINEERING RESEARCH JOURNAL \\
\hline & Faculty of Engineering - Port Said University \\
Volume (21) No. (2) September 2017 pp. 98:102
\end{tabular}

\title{
Stress-Strain Distribution in High Strength Self Compacted Concrete Deep Beam
}

\author{
H.M. Hassan ${ }^{1}$, M.A. Arab² and A.I. EL-kassas ${ }^{3}$
}

\begin{abstract}
Beam is classified as a deep beam if the beam has a larger depth in relation to spans. Deep beam differ from normal beam in which they are most likely to have strength controlled by shear rather than flexure. In addition, deep beams have been widely used as a transfer girder in offshore structures as well as foundations. Moreover, the failure behaviour of deep beams is significantly not the same from the one which are shallow due to the geometry and load transfer mechanism. This research presented the stress-strain distribution results for four identical high strength self compacted concrete (HSSCC) deep beams. From the indicated results, it could be concluded that, the strain distribution at mid span was non linear at all loading increments and the compression strain at the top of mid span section increased with the increasing of the applied load. There is a disturbance in tension strain values due to the crack propagation and the deformation of this area. From the stress distribution of deep beam, it could be indicated that neutral axis is at the middle third of the beam depth and is tends slightly to the upper direction.
\end{abstract}

\section{INTRODUCTION}

During the last several decades there has been an increased popularity in deep beams within high-rise buildings, offshore structures and foundations [12].

Deep beams are defined as members loaded on one face and supported on the opposite face so that compression struts can develop between the loads and the supports. Their clear spans are either equal to or less than four times the overall member depth; or regions with concentrated loads within twice the member depth from the face of the support, ACI 318-14 [1]. The EC 203-12 [7] adopts the same definition as ACI318-14. These structural elements belong to $\mathrm{D}$ (Disturbed) regions, which have traditionally been designed using empirical formulae or using past experience [3].

In a high rise building, these beams can generally be found within the lower section of the building, particularly between the residential and office section for mixed use structures, where they are incorporated as continuous transfer girders [9].

The structural behavior of deep beams is not completely understood. Deep beam differs from ordinary beam in which they are most likely to have strength controlled by shear rather than flexure. The high depth to span ratio causes nonlinearity in the elastic flexural stress distribution over the beam depth and their strength is usually

\footnotetext{
1 Prof. of Civil Engineering Department, Faculty of Engineering, Port Said University, Port said, Egypt, E-mail: hi hgh@yahoo.com

2 Lecture in Civil Engineering Department, Faculty of Engineering, Beni-suief University, Beni-suief, Egypt, E-mail: emarab@eng.bsu.edu.eg

3 Administrator in Civil Engineering Department, Faculty of Engineering, Sinai University, North sinai, Egypt, E-mail: ahmed.elqassas@su.edu.eg
}

controlled by shear, rather than flexure [9].

Furthermore, deep beams are highly sensitive to imposed deformations, such as differential support settlements, because of their large bending stiffness [10].

In deep beams, the transverse sections which are plane before bending do not remain plane after bending $[10,11]$. The neutral axis does not usually lie at mid-depth and moves away from the loaded face of the member as the span to depth ratio decreases. Flexural stresses and strains are not linearly distributed across the beam depth $[10,11]$ as shown in the fig.1.

Further, the development of construction materials provides engineers more choices to utilise high strength materials which are popular for highrise buildings. The benefit of using high strength concrete in buildings is varied such as resistance to noise, vibration and thermal control. Despite the fact that using high strength concrete adds complexity on the behaviour of structure, the trend of current construction is heading towards more utilisation of high strength concrete and this trend has been demonstrated in the most recent national codes [12].

For several years, the problem of durability of concrete structures has been a major problem posed to engineers. The creation of durable concrete structures requires adequate compaction by vibration. Over vibration can easily cause segregation [5].

Rebars' overcrowded arrangement in reinforced concrete members, such as deep beams, makes it difficult to compact concrete properly with the use of a mechanical vibrator. Self-compacting concrete (SCC) is a preferred substitution for conventional concrete where highly congested reinforcement is 
present or forms with complex shapes need to be filled. It is able to flow and consolidate under its own weight without the need for mechanical vibration [6].

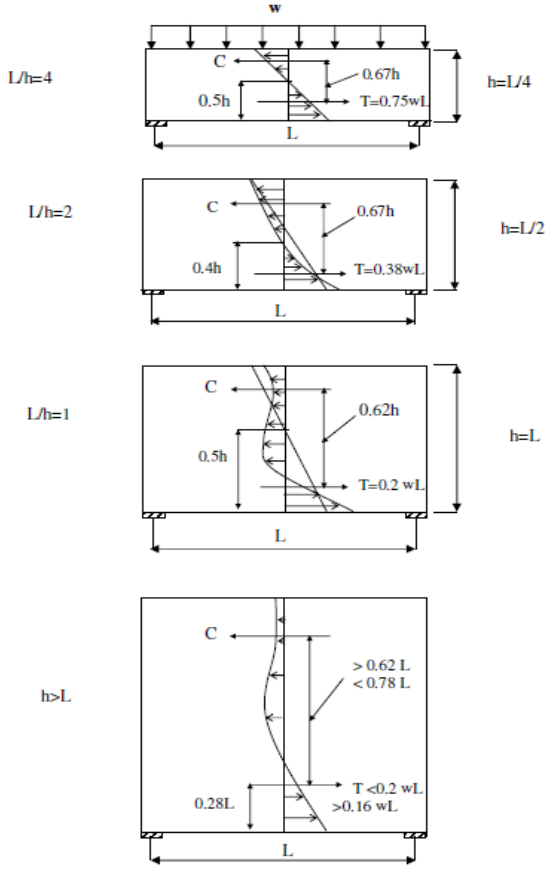

Fig.1: Distribution of Flexural Stresses in Homogeneous Simply Supported Deep Beam

\section{RESEARCH SIGNIFICANCE}

The main goal of this research is to study the stress-strain distribution along the beam section at mid-span and discuss the variation of the neutral axis within the depth.

\section{Materials Used and Experimental Program}

\subsection{Materials}

Due to technical and economical justification it was decided to use high strength self-compacted concrete. SCC is a highly flowable, non-segregating concrete that can spread into the mold and fill the formwork and encapsulate the reinforcement without any need for consolidation. Slump flow and J-Ring tests were used for measuring the degree of workability for HSSCC mix, Test results were accepted according to British standard (BS EN 206-9, 2010) [4] and Egyptian code (E.C.P. 203/2012) [7] as shown in fig.2. The HSSCC mix design is given in table 1 . In the mix design, cement used was ordinary Portland cement CEM I 52.5N. Natural and clean sand with a specific gravity $2.71 \mathrm{t} / \mathrm{m}^{3}$ and fines modulus 2 . Crushed Dolomite of maximum nominal size $12.5 \mathrm{~mm}$ and specific gravity $2.65 \mathrm{t} / \mathrm{m}^{3}$ is used as coarse aggregate. Sika Viscocrete 3425 is the used superplasticizer it is a polycarboxylate based super- plasticizer supplied by Sika Egypt, which meets the requirements of super-plasticizer according to ASTMC-494 [2], types G and F. The used super-plasticizer has $1.08 \mathrm{Kg} /$ lit density, and $40 \%$ solid content (by weight). The density and fineness of the silica fume used were $2210 \mathrm{~kg} / \mathrm{m}^{3}$ and $23.52 \mathrm{~m}^{2} / \mathrm{gm}$, respectively. The used silica fume was met the main requirement of ASTM C 1240.

Two types of steel reinforcement were used as shown in table 2 . The first was the mild steel which is used as vertical and horizontal shear reinforcement. The second type was the high tensile steel which used for the upper and lower reinforcement.

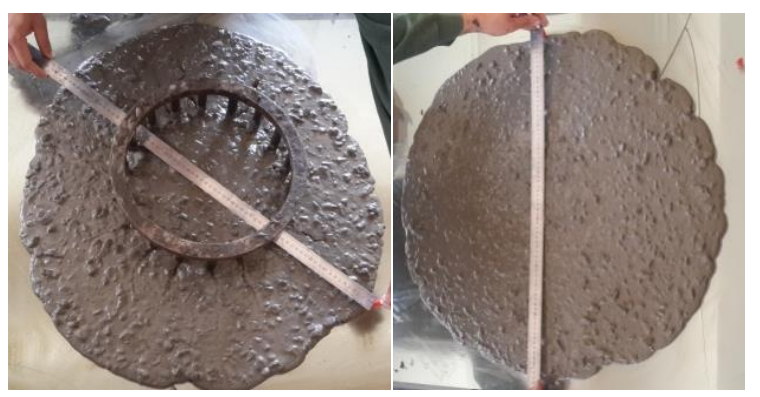

Fig. 2: J-Ring tests \& Slump flow

Table 1: HSSCC mix design.

\begin{tabular}{|c|c|}
\hline Cement $\left(\mathrm{Kg} / \mathrm{m}^{3}\right)$ & 550 \\
\hline Silica fume $\left(\mathrm{Kg} / \mathrm{m}^{3}\right)$ & 27.5 \\
\hline Coarse aggregate $\left(\mathrm{Kg} / \mathrm{m}^{3}\right)$ & 762 \\
\hline Fine aggregate $\left(\mathrm{Kg} / \mathrm{m}^{3}\right)$ & 762 \\
\hline Water (Litre $/ \mathrm{m}^{3}$ ) & 184.8 \\
\hline Super-plasticizer (Litre/m³) & 6.93 \\
\hline Slump of concrete Diam. $(\mathrm{Cm})$ & $>65$ \\
\hline Time of slump $T_{50 \mathrm{~cm}}(\mathrm{sec})$ & 4.2 \\
\hline Different high of J-ring (Cm) & 0.4 \\
\hline Characteristic cube strength (MPa) & 73.6 \\
\hline
\end{tabular}

Table 2: Mechanical Properties of Steel Rft

\begin{tabular}{c|c|c|c}
\hline Steel Type & $\begin{array}{c}\text { Yield } \\
\text { Stress }\left(\mathrm{Kg} / \mathrm{cm}^{2}\right)\end{array}$ & $\begin{array}{c}\text { Tensile } \\
\text { Strength }\left(\mathrm{Kg} / \mathrm{cm}^{2}\right)\end{array}$ & $\begin{array}{c}\text { Elongation } \\
(\%)\end{array}$ \\
\hline Mild St. & 2950 & 3990 & 22.2 \\
\hline $\begin{array}{c}\text { High } \\
\text { Tensile St. }\end{array}$ & 3680 & 5310 & 13.2 \\
\hline
\end{tabular}

\subsection{Experimental Program}

The experimental work consists of four identical high strength concrete (HSC) deep beams casted with self compacted concrete (SCC) to investigate the stress-strain distribution for deep beam.

Four RHSSCC deep beams have been cast; the experimental program was carried out to investigate the deep beams' stress-strain distribution and the neutral axis variation with different load increments.

\subsection{Deep Beams Casting}

Deep beam was cast in mould of dimension 150x300x1100mm. Deep beam was of dimension and RFT as shown in the fig.3. Beam was cast to be tested 


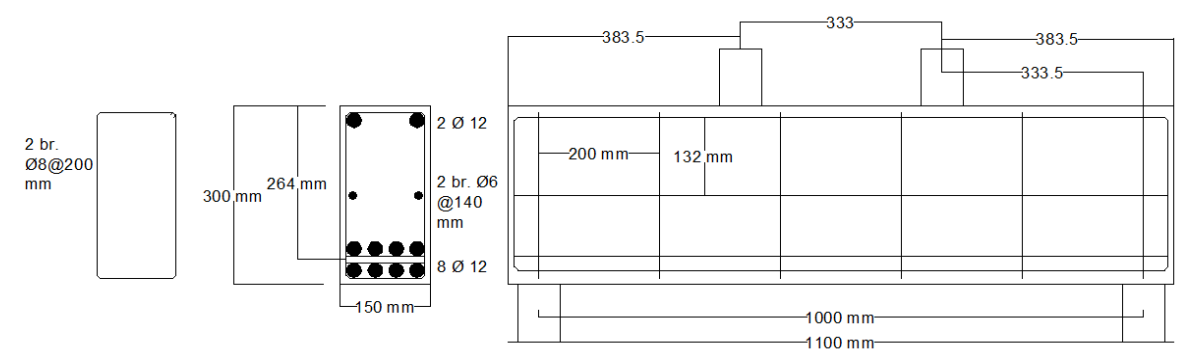

Fig. 3: The RFT details for tested beams

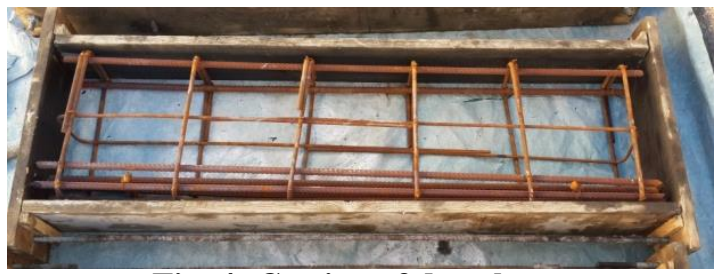

Fig. 4: Casting of deep beam
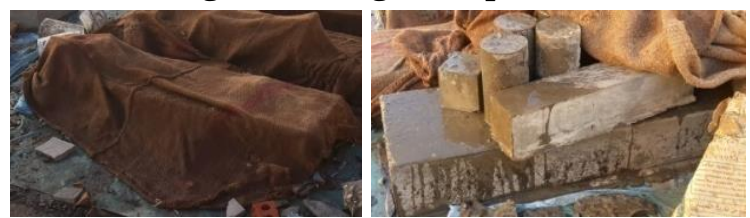

Fig. 5: Beams curing

and cured with wet canvas till testing as shown in figs. 4,5 after 28 days also 6 cubes were cast to be sure of the compressive strength.

\subsection{Four Point Load Test Procedure}

A steel frame with two movable I-beam girders was used as a support for beams. The load was applied by a hydraulic cylinder double acting with 150 ton capacity and $150 \mathrm{~mm}$ maximum stroke which was connected to a hydraulic pump. The applied load was measured by a load cell of 225 ton capacity. Figure 6 shows the loading frame and equipments. An LVDT for measuring displacements up to $100 \mathrm{~mm}$ was placed under each beam at the center of its span to measure deflections within the region of pure bending between the two load points. The load cell and the LVDT were connected to a data logger that shows a continuous record of the applied load and the corresponding deflection at mid span.

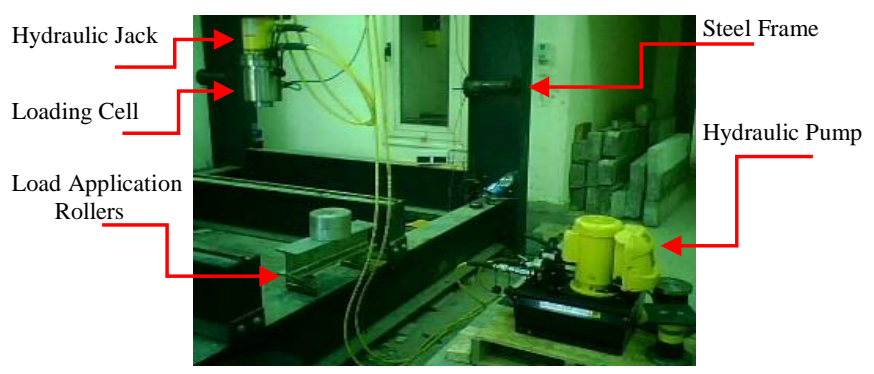

Fig. 6: Loading frame and equipments

\subsection{Deep Beam's Strain Distribution}

Figure 7 shows the mechanical strain gauge that explains the setting out bar which used to position pre-drilled stainless steel discs (Demec points) which are attached to the structure using a suitable adhesive materials. Demec points have been attached at $10 \mathrm{~cm}$ from center on two sides at each $5 \mathrm{~cm}$ of beam depth as shown in fig. 8. Deep beam's stress distribution was measured at different loading increment at each opposite button.

For data collection, the first readings were those under the self weight of beams and then the loading process was carried out with an increment of $15 \mathrm{KN}$ until first crack appeared. All beams were tested till failure under two -point loading (Four point load test).

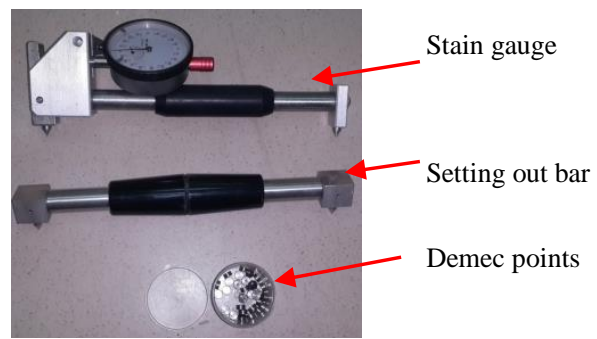

Fig. 7: Mechanical Strain gauge equipment

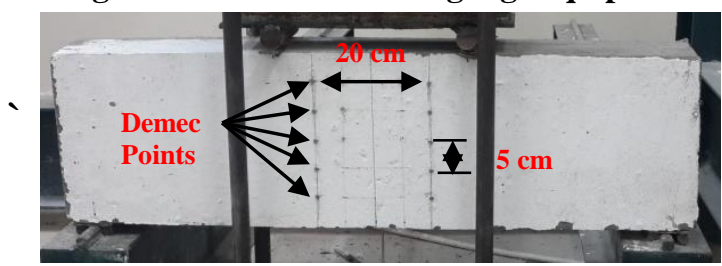

Fig. 8: preparing for testing

\section{Test Results and Discussion}

From the data collected through strain gauges reading, the strain distribution within the beam section depth has been investigated and drawn. The mean of the four beam results was presented in table 3 below.

The compression strain at the top of mid span section increases as the load increases, but in the tension area the various recorded values were disturbed by the cracks and the flexibility of this area.

For a better description of the strain distribution during the loading process, graphs were drawn and presented in Fig. 9 for 16 loading increments.

As shown in Fig. 9, at the load around ultimate state, the compressive stress distribution in the concrete no longer follows the expected parabolic shape but showed almost linear shape. This condition is due to the predomination effect of horizontal bar 
after the occurrence of crack and reducing the concrete compression area.

Table 3: Strain values at different loading increment

\begin{tabular}{|r|c|c|c|c|c|}
\hline \multirow{2}{*}{$\begin{array}{c}\text { Load } \\
\text { (KN) }\end{array}$} & \multicolumn{3}{|c|}{ Strain $10^{-3}$ at different location along beam } \\
\cline { 2 - 6 } & 5 & 10 & 15 & 20 & 25 \\
\hline 14.5 & 0.15 & -0.2625 & -0.28 & -2.8 & -0.035 \\
\hline 28.2 & 0.2 & -0.3125 & -0.405 & -0.455 & -0.085 \\
\hline 41.7 & 0.205 & -0.0825 & -0.055 & -0.065 & -0.095 \\
\hline 55.4 & 0.355 & -0.0525 & -0.05 & -0.01 & -0.06 \\
\hline 69.5 & 0.425 & -0.0875 & -0.01 & -0.005 & -0.05 \\
\hline 83.2 & 0.365 & -0.0625 & -0.015 & -0.02 & -0.055 \\
\hline 96.9 & 0.645 & -0.0575 & 0.0125 & -0.045 & -0.065 \\
\hline 111.3 & 0.645 & -0.0325 & 0.035 & -0.0125 & -0.075 \\
\hline 124.9 & 0.6 & -0.0825 & 0.035 & -0.025 & -0.075 \\
\hline 138.9 & 0.705 & -0.0625 & 0.045 & -0.02 & -0.09 \\
\hline 153 & 0.92 & -0.1225 & -0.035 & -0.12 & -0.105 \\
\hline 180.5 & 1.05 & -0.1125 & -0.005 & -0.035 & -0.14 \\
\hline 194.6 & 0.96 & -0.1275 & 0.06 & -0.05 & -0.165 \\
\hline 208.3 & 0.925 & -0.0525 & 0.1 & -0.045 & -0.19 \\
\hline 222.1 & 0.965 & 0.0125 & 0.08 & -0.05 & -0.195 \\
\hline 249.5 & 0.98 & -0.0125 & 0.12 & -0.03 & -0.225 \\
\hline 263.5 & 1.06 & 0.0575 & 0.125 & -0.06 & -0.23 \\
\hline 277.1 & 1.12 & 0.1025 & 0.17 & -0.045 & -0.25 \\
\hline 291.9 & 1.05 & -0.0125 & 0.18 & -0.05 & -0.265 \\
\hline 306.7 & 1.07 & 0.0775 & 0.19 & -0.055 & -0.31 \\
\hline 319.1 & 0.725 & -0.0325 & 0.135 & -0.135 & -0.355 \\
\hline 331.7 & 1.025 & 0.1175 & 0.22 & -0.055 & -0.31 \\
\hline 346.1 & 1.105 & 0.1775 & 0.245 & -0.06 & -0.35 \\
\hline 360.3 & 1.205 & 0.1375 & 0.24 & -0.07 & -0.37 \\
\hline 373.8 & 1.355 & 0.2275 & 0.285 & -0.045 & -0.4 \\
\hline 389.3 & 1.225 & 0.3275 & 0.305 & -0.035 & -0.415 \\
\hline 403.4 & 1.38 & 0.3425 & 0.315 & -0.055 & -0.43 \\
\hline 416 & 1.315 & 0.3225 & 0.3 & -0.055 & -0.43 \\
\hline 429.7 & 1.51 & 0.3975 & 0.325 & -0.065 & -0.465 \\
\hline 443.6 & 1.475 & 0.4375 & 0.32 & -0.055 & -0.48 \\
\hline 457.3 & 1.5 & 0.4275 & 0.34 & -0.08 & -0.52 \\
\hline 470.8 & 1.535 & 0.4475 & 0.345 & -0.035 & -0.51 \\
\hline 484.5 & 1.625 & 0.4625 & 0.37 & -0.085 & -0.53 \\
\hline 498.8 & 1.89 & 0.5675 & 0.385 & -0.085 & -0.555 \\
\hline 512.6 & 1.795 & 0.3875 & 0.335 & -0.1 & -0.58 \\
\hline 526.4 & 1.875 & 0.4675 & 0.28 & -0.1 & -0.64 \\
\hline 540.8 & 1.975 & 0.4075 & 0.225 & -0.12 & -0.665 \\
\hline 553.9 & 1.925 & 0.7675 & 0.46 & -0.105 & -0.69 \\
\hline 567.4 & 1.98 & 0.5375 & 0.32 & -0.105 & -0.715 \\
\hline 582.2 & 2.08 & 0.7225 & 0.355 & -0.15 & -0.74 \\
\hline & & & & & \\
\hline
\end{tabular}

According to these Figures, the compression strain is very low in comparison compared with those in normal beams. This aspect should be taken into account when designing a deep beam since the maximum strain at the extreme compression fiber is comparatively small.

From the stress distribution of deep beam, it could be indicated that neutral axis is at the middle third of the beam depth and is tends slightly to the upper direction.

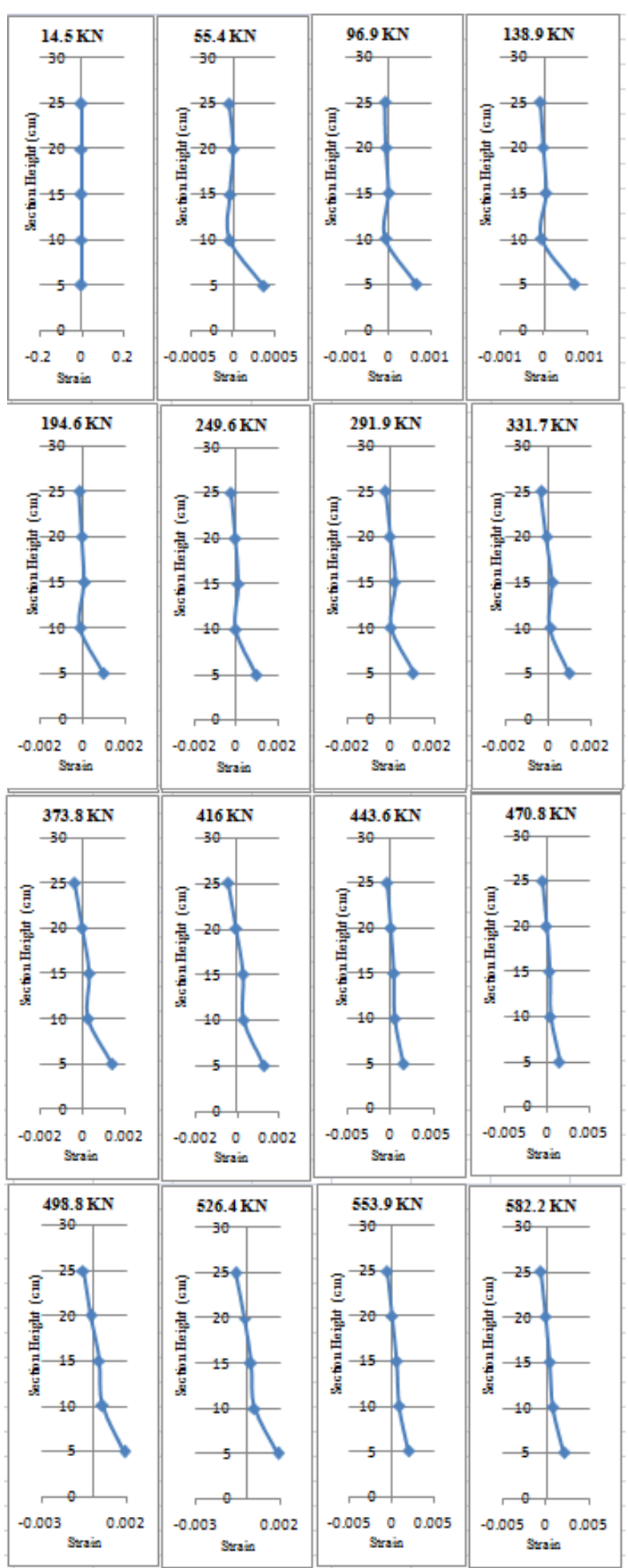

Fig. 9: Strain distribution for loading increments.

\section{CONCLUSION}

Observing of the behavior of deep beams is of a great important in modern construction buildings. 
The first step to understand this behavior is to study the stress-strain distribution along the deep beam depth. This research presented the stress-strain distribution results for four identical high strength self compacted concrete (HSSCC) deep beams. From the indicated results, it could be concluded that, the strain distribution at mid span was non linear at all loading increments and the compression strain at the top of mid span section increased with the increase of the applied load. There is a disturbance in tension strain due to cracks propagation and the deformation of this area. From the stress distribution of deep beam, it could be indicated that neutral axis is at the middle third of the beam depth and is tends slightly to the upper direction.

\section{REFERENCE}

[1] ACI Committee 318, (2014), "Building Code Requirements For Reinforced Concrete (ACI 318-14) and commentary (ACI 318R-14)," American Concrete Institute, Farmington Hills, Mich.

[2] American Society for Testing and Materials (ASTM), 2003. ASTM C494: Chemical Admixtures. ASTM International, Philadelphia, USA.

[3] Ammar N. Hanoon, M.S. Jaafar a , Farzad Hejazi a , Farah N.A. Abdul Aziz, (2017), "Strut-and-Tie Model for Externally Bonded CFRP-Strengthened Reinforced concrete Deep Beams Based on Particle Swarm Optimization Algorithm: CFRP Debonding and Rupture, Construction and Building Materials 147 (2017) 428-447.

[4] British Standards Institution, (1985). The Structural Use of Concrete. BS 8110, British Standard Institution, London (Parts 1 and 2). Canadian Standards Association, 1984. Design of Concrete.

[5] Broomfield, J. (2003). The Identification And Assessment Of Defects, Damage And Decay. In S. MacDonald (Ed.), Concrete: Building pathology. Oxon: Blackwell.

[6] Domone, P. L. (2006). Self-Compacting Concrete: An Analysis Of 11 Years Of Case Studies. Cement and Concrete Composites, 28, 197-208.

[7] Egyptian Code of practice, Permanent Committee For the code, (2012), "Design And Construction Of Reinforced Concrete Structures "Fourth Edition, Housing and Building research Center and Physical Planning, Cairo, Egypt.

[8] Khaled M. Heiza, N. N. Meleka , N. Y. Elwkad, (2012), "Shear Strengthening Of Self-Compacting Reinforced Concrete Deep Beams With External Bonded Layers", Concrete Research Letters Vol. 3(4).
[9] Nagarajan. P, Madhavan, P.T.M., (2008), "Development Of Strut And Tie Models For Simply Supported Deep Beams Using Topology Optimization", Songklanakarin J. Sci. Technol. 30 (5), 641-647.

[10] Nilson, A. H., and Darwin, D., (1997), "Design Of Concrete Structures," McGrawHill International Editions, 12th Edition, pp. 151.

[11] Winter, G., and Nilson, A.H., (1978), "Design Of Concrete Structures", 9th Edition.

[12] Yoo, T. M., (2011), "Strength And Behaviour Of High Strength Concrete Deep Beam With Web Openings". PhD Thesis, Griffith School of Engineering, Griffith University. 